\title{
Pseudolamarckina pseudorjasanensis Dain, 1967 (Foraminifera) as a Kimmeridgian marker species and its significance for biostratigraphy, palaeoecology and palaeobiogeography
}

\author{
Clémentine Peggy Anne-Marie Colpaert ${ }^{1,2}$ \& Boris Leonidovich Nikitenko ${ }^{1,2}$ \\ 1 Trofimuk Institute of Petroleum Geology and Geophysics, Siberian Branch of the Russian Academy of Sciences, Novosibirsk, Russia; \\ ${ }^{2}$ Novosibirsk State University, Novosibirsk, Russia
}

\begin{abstract}
This study presents a taxonomical review of the species Pseudolamarckina pseudorjasanensis Dain, 1967 collected at different sampling levels from the central and northern parts of European Russia and from Western Siberia. Morphological and biometrical analyses show that P. pseudorjasanensis is characterized by wide intraspecific variabilities and may encompass various previously described Kimmeridgian species of the genus Pseudolamarckina. The first appearance of P. pseudorjasanensis is recorded from the latest Early Kimmeridgian of subMediterranean to Arctic regions. Furthermore, P. pseudorjasanensis appears to be the marker species of the foraminiferal JF4l Zone in Kimmeridgian sections of sub-boreal, boreal and Arctic regions. This JF4l Zone is particularly significant for interregional correlations. Finally, P. pseudorjasanensis was widespread across the Kimmeridgian basins of the Northern Hemisphere and was associated with environments predominantly located in the middle sublittoral zone.
\end{abstract}

\author{
Keywords \\ Foraminifera; systematics; Arctic; Jurassic; \\ biogeography; palaeoenvironments

\section{Correspondence \\ Clémentine Colpaert, Trofimuk Institute of Petroleum Geology and Geophysics, Siberian Branch of the Russian Academy of Sciences, pr. Akademika Koptyuga 3, 630090 Novosibirsk, Russia. E-mail: clementinecolpaert@gmail.com}

\begin{abstract}
Abbreviations
$\alpha_{a p}$ : angle of the arcuate arrangement of the aperture; $\alpha_{\mathrm{nm}}$ : angle of the lobate arrangement of the peripheral margin; $\alpha_{\text {sulwh }}$ : angle of the suture spiral; CVA: canonical variate analysis; $\mathrm{D}_{\mathrm{ap}}$ : distance peripheral margin to aperture by total rayon of the test; $D_{p r}$ : length of the proloculus; $D_{\text {pr }} / L$ : proportion of the proloculus; L: length; $L_{a p}$ : length of the aperture; MANOVA: multivariate analysis of variance; $\mathrm{N}_{\mathrm{ch}}{ }_{\mathrm{c}}$ : total number of chambers; $\mathrm{N}^{\circ}$ : number of chambers in the last whorl; $\mathrm{N}^{\circ}{ }_{\text {chllwh }} / \mathrm{N}^{\circ}$ ch : the proportion of chambers in the last whorl; $\mathrm{N}^{\circ}$ wh number of whorls; S: Section (e.g., S1); T: thickness; $T / L$ : conical rate; $T_{\text {sur }}$ : thickness of the suture in the early whorls; $T_{\text {sullwh }}$ : thickness of the suture in the last whorl; $T^{\text {sulwh }} / T$ late by early whorl's suture thickness rate; W: width; W/L: elongated rate
\end{abstract}

\section{Introduction}

The study of the Kimmeridgian strata of Europe and Western Siberia dates back to the end of the 19th century and the beginning of the 20th century. Investigations of foraminifers were initially focussed on the taxonomical composition of the recorded taxa. In the second half of the 20th century, the rise of the petroleum industry encouraged the first biostratigraphical analyses. At that time, most of the micropalaeontological investigations in different regions of western, eastern and northern Europe, as well as Western
Siberia, were performed separately. Various interpretations of the observed taxa made it difficult to make interregional correlations. Therefore, only a small proportion of the widespread foraminiferal taxa is useful for interregional correlations between the sub-Mediterranean and the Arctic.

Pseudolamarckina rjasanensis (Uhlig, 1883) was firstly described as the single species of the genus Pseudolamarckina (Mjatljuk, 1959), ranging from Callovian to Kimmeridgian times (Bykova 1948; Mjatljuk 1959; Umanskaja 1965; Stam 1986). There were many reports of mass accumulations of Pseudolamarckina individuals, especially 
from the Middle to the Upper Callovian and the uppermost part of the Kimmeridgian (Umanskaja 1965; Dain \& Kuznecova 1976; Stam 1986; Azbel' \& Grigjalis 1991). Later, detailed monographic analyses showed that Callovian and Kimmeridgian specimens had to be attributed to different species, and multiple taxonomical descriptions were subsequently published over the years, including those of the Kimmeridgian species from the central part of European Russia: P. pseudorjasanensis (Kamyševa-Elpat'evskaja 1967; Dain \& Kuznecova 1976), P. polonica spatiosa Dain, 1976 (partly) (Dain \& Kuznecova, 1976), P. dainae Starceva, 1972; as well as from the northern part of European Russia and Siberia: P. lopsiensis Dain, 1972 and P. liapinensis Dain, 1972 (Dain 1972). Kimmeridgian specimens from different marine basins were attributed to different species, because of the application of the concept of provincialism (Dain 1972). Late Kimmeridgian species of the genus Pseudolamarckina described in the central part of European Russia were extensively observed in sections from western and eastern Europe (Belecka \& Kuznecova 1969; Kuznecova 1979; Stam 1986; Smoleń \& Iwańczuk 2018), as were the Siberian species in sections from Arctic Alaska and Canada (Hedinger 1993; Nikitenko 2009; Nikitenko et al. 2013; Nikitenko et al. 2015).

The taxonomical analysis of the Kimmeridgian species of the genus Pseudolamarckina is therefore particularly significant in the modernization of interregional biostratigraphical correlations based on foraminifers. Furthermore, species belonging to the genus Pseudolamarckina
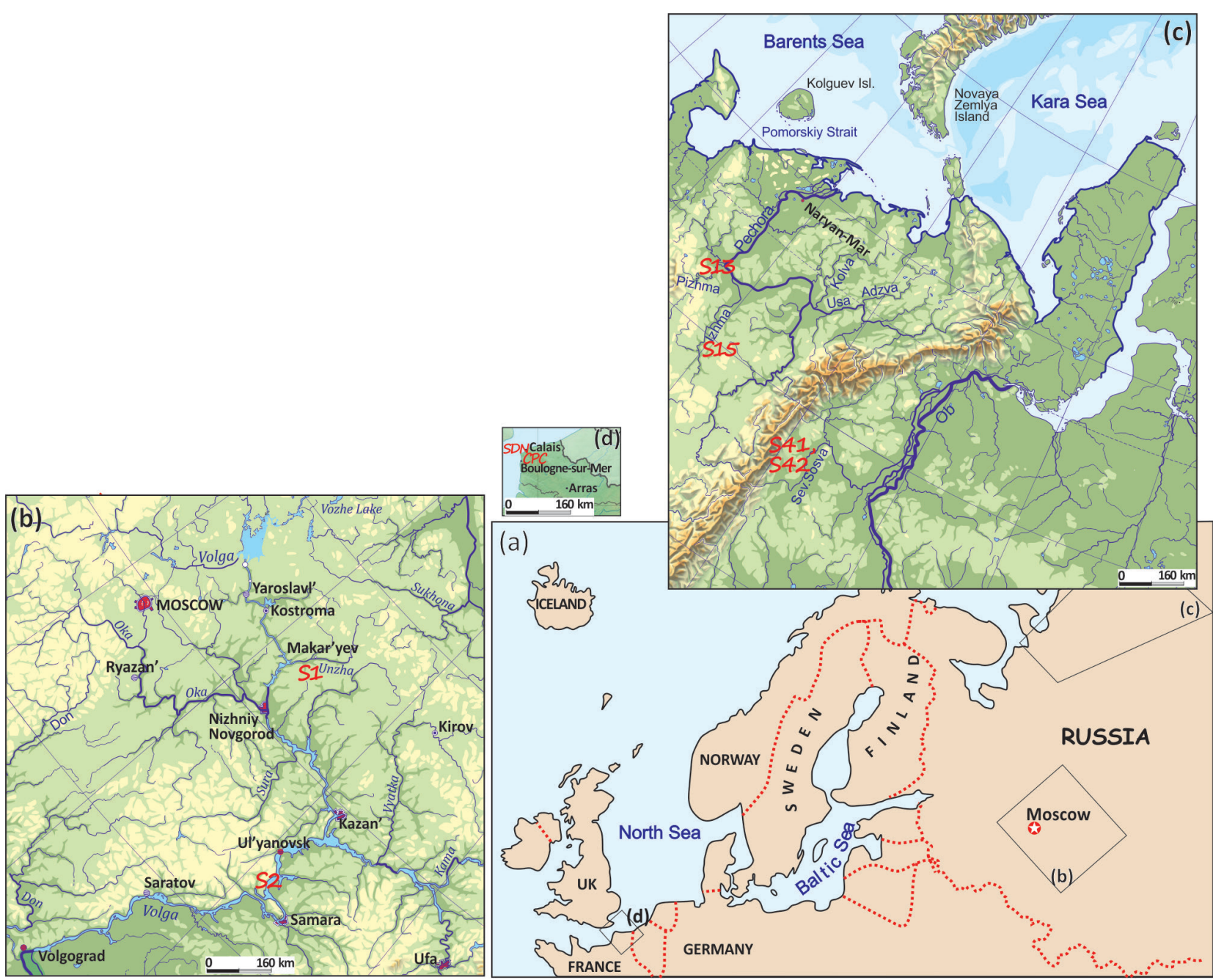

Fig. 1 (a) Map of the northern Europe and Western Siberia; (b) central part of European Russia, with locations of Makar'yev (S1) and Gorodishche (S2) sections indicated; (c) northern part of European Russia and Western Siberia, with locations of Vyatkina River (S13), Izhma River (S15) and Lopsiya River (S41-S42) sections indicated (d) western Europe (Boulonnais Region). 
often constitute a dominant part of the microfossil associations in the upper half of the Kimmeridgian in subboreal, boreal and Arctic basins, and can be successfully used in palaeoecological and biogeographical reconstructions (Nikitenko 2009). Recent studies have proved that many of the previously described Kimmeridgian species of the genus Pseudolamarckina have to be attributed to a single species characterized by high intraspecific variability (Levčuk \& Nikitenko 2010). The present study proposes a taxonomical revision of specimens from the boreal and Arctic, focussing on the high intraspecific variabilities of species of the genus Pseudolamarckina, in order to better understand their significance for interregional correlations across the sub-Mediterranean, sub-boreal, boreal and Arctic palaeo basins.

\section{Material and methods}

The studied specimens of the genus Pseudolamarckina (Mjatljuk, 1959) are derived from four different sampling levels (Fig. 1), as follows: (1) Representing the Lower Kimmeridgian ammonite Cymodoce Zone is the Makar'yev Section (S1) in Kostroma district, central European Russia (East European Platform) (Colpaert et al. 2016; Colpaert, Nikitenko et al. 2017). (2) Representing the Upper Kimmeridgian ammonite Eudoxus-Autissiodorensis zones is the Gorodishche Section (S2) in Yl'yanovsk district, central European Russia (East European Platform) (Colpaert, Pestchevitskaya et al. 2017). (3) Representing the uppermost Lower and Upper Kimmeridgian are the Vyatkina and Izhma River sections (S13, S15) in northern European Russia (Timan-Pechora Basin) (Mesežnikov 1984). (4) Representing the uppermost Lower and Upper Kimmeridgian ammonite Borealis-Autissiodorensis zones is the Lopsiya River Section (S41, S42) in Subpolar Ural, Western Siberia (Nikitenko 2009). In addition, specimens of the genus Pseudolamarckina from the Lower Volgian were studied for comparative analysis. They are derived from two different sampling levels (Fig. 1): Gorodishche Section (S2) (Colpaert, Pestchevitskaya et al. 2017): ammonite Klimovi Zone; and Lopsiya River Section (S41) (Nikitenko 2009): ammonite Magnum-Subcrassum zones. The studied specimens are stored in the micropalaeontological collections of the Institute of Petroleum Geology and Geophysics, Siberian Branch of the Russian Academy of Sciences, Novosibirsk.

This study uses the terminology and classification proposed by Loeblich $\&$ Tappan (1987). In addition, a number of quantitative parameters have been selected on the basis of previously proposed descriptions of species of the genus Pseudolamarckina (Mjatljuk 1959; KamyševaElpat'evskaja 1967; Dain1972; Bulynnikova et al. 1990; Glinskikh et al. 1999; Levčuk \& Nikitenko 2010) and are illustrated in Fig. 2.

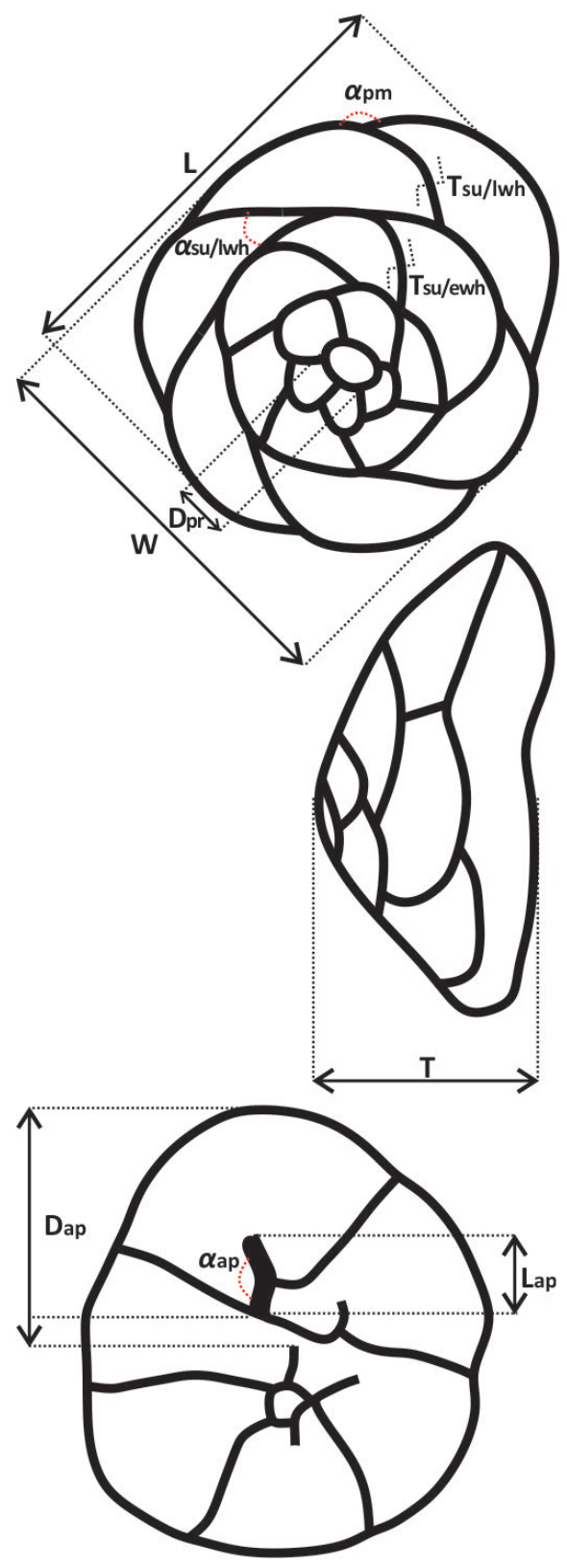

Fig. 2. Biometrical parameters used in the taxonomical review of Pseudolamarckina pseudorjasanensis.

Finally, a discriminant analysis by means of CVA was performed in order to graphically and statistically evaluate how the studied specimens can be distinguished based on the biometrical parameters. Since the studied parameters are of different types (size, ratio and ordinal), the CVA was performed on the correlation matrix (data standardized to mean zero and unit standard deviation) for all parameters in order to avoid a scale bias. The purpose of this standard ordination method is to project the multidimensional data set (composed in this case of the test parameters) on newly 
constructed axes, which maximizes the discrimination between given groups (here, the taxa) (Hammer \& Harper 2006). This method is a convenient tool to find differences between taxa in the function of the parameters, as well as to the value of each parameter. This method allows us to identify the parameters contributing to the morphological definitions of the species and the specimens order along the new major axes that represent their morphological differences. In addition to the MANOVA, the efficiency of the tested parameters in discriminating the studied taxa is also evaluated by the confusion matrix, which provides a comparative analysis of the automatic classification based on test parameters and on original classification.

\section{Systematic description}

Class Foraminifera Eichwald, 1860

Order Lagenida Delage and Hérouard, 1896

Superfamily Ceratobuliminicea Cushman, 1927

Family Ceratobuliminidae Cushman, 1927

Subfamily Reinholdellinae, Seiglie and Bermúdez, 1965

Genus Pseudolamarckina Mjatljuk, 1959

Pseudolamarckina pseudorjasanensis Dain, 1967

Figs. 3, 4 and 5

Lamarckina(?) rjasanensis: Mjatljuk 1953: 206, pl. 1, fig. 3a-b.

Pseudolamarckina rjasanensis: Mjatljuk 1959: 278, fig. 513a-b; Umanskaja, 1965: 100, pl. 4, fig. 4; Stam 1986: 124-125, pl. 3, figs. 7-9, 11-12.

Pseudolamarckina pseudorjasanensis: Dain, in KamyševaElpat'evskaja 1967: 164, pl. XXVI, fig. 4a-c; Dain \& Kuznecova 1976: 121-123, pl. XXIV, figs. 1-5; Azbel'\& Grigjalis 1991, pl. 28, fig. 9; Lyjurov 1996, pl. 8, fig. 3.

Pseudolamarckina lopsiensis: Dain 1972: 171, pl. LIII, figs. 3-7, pl. LV, figs. 2-8, pl. XIX, figs. 6-8; Bulynnikova et al. 1990: 179, pl. 65, figs. 1-5; Glinskikh et al. 1999: 1075, fig. 8; Nikitenko 2009, pl. f-54, figs. 4-15, pl. 55, figs. 1-12; Levčuk \& Nikitenko 2010: 94-95, pl. III, figs. 20-24.

Pseudolamarckina liapinensis: Dain 1972: 169, pl. LII, figs. 1-6, pl. LV, figs. 1-9, pl. XIX, figs. 7, 9, 11; Bulynnikova et al. 1990: 179, pl. 64, figs. 1-7; Hedinger 1993: 103, pl. 28, figs. 1-8.

Pseudorlamarckina dainae: Starceva 1972: 117-121, pl. II, figs. 3-5; Azbel'\& Grigjalis 1991, pl. 27, fig. 8; Smoleń \& Iwańczuk 2018, fig. 20R.

Pseudolamarckina polonica spatiosa: Dain \& Kuznecova 1976: 123-124, pl. XXVIII, figs. 1-7.

\section{Topotype}

Specimens no. 428/60 and no. 428/62, All-Russia Petroleum Research Exploration Institute (VNIGRI); Dain $\delta$
Kuznecova 1976, pl. XXVI, figs. 1, 4; Ul'yanovsk Region, Gorodishche Village; Upper Kimmeridgian, ammonite Mutabilis Zone.

\section{Paratype}

Specimen no. 428/61, All-Russia Petroleum Research Exploration Institute (VNIGRI); Dain \& Kuznecova 1976, pl. XXVI, fig. 5; Tatarstan, Karla River; Upper Kimmeridgian, ammonite Eudoxus Zone.

\section{Material}

A total of 107 specimens in good preservation and without traces of any kind of transportation. Makar'yev Section, S1, seven specimens; Gorodishche Section, S2, 58 specimens; Vyatkina and Izhma River sections, S13 and S15, five specimens; Lopsiya River Section, S41, 37 specimens (Fig. 1).

\section{Description}

Test trochospiral, rounded in outline, almost conical in lateral view, peripheral margin tapered. Dorsal side regularly convex; ventral side slightly convex to slightly depressed. The test consists in 9-20 chambers, distributed over two to four whorls; last whorl is made of five to nine chambers. The early chambers, small and rounded, are located in the dorsal side on the top of the conus. Later chambers are oblique, trapezoidal and semi-circular in shape, slowly increasing in size. Last whorl is separated from the previous one by a rolling spiral with chambers overlying the ventral side. Sutures oblique, arcuate are covered by overlying ridges, and they merge with the spiral along an angle varying from $32^{\circ}$ to $79^{\circ}$ (mean values around $45^{\circ}$ ); some sutures of different thickness, sometimes raising on the first whorls, later narrow on the last whorls. Spiral and septal sutures bend towards the ventral side in the peripheral margin. The peripheral margin strongly lobates, sometimes gently. The proloculus is located in the centre of the dorsal side, at $1 / 10$ to $1 / 2.5$ of the total test size (mean values around 1/5). The aperture opens near the centre of the ventral side, and is loop-shaped towards the centre of the test, transversal with the base of the earlier chamber.

\section{Measurement}

Table 1 (in $\mathrm{mm}$ ).

\section{Variations}

The species are characterized by very high intraspecific variations through the different stages of the ontogenesis. 


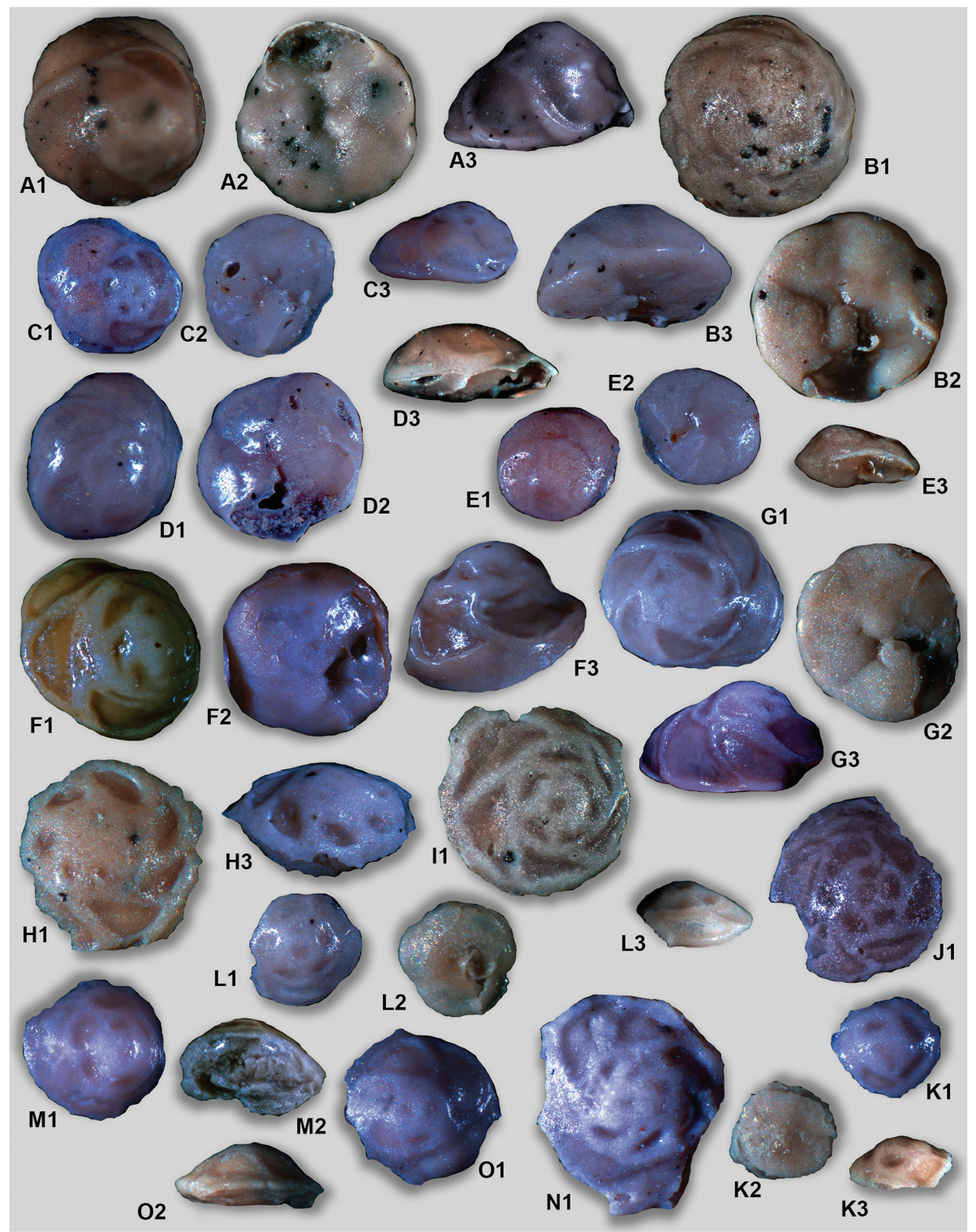

Fig. 3 Dorsal (1), ventral (2) and lateral (3) views of Pseudolamarckina pseudorjasanensis Dain, 1967 specimens in the Lower and Upper Kimmeridgian of the central and northern European part of Russia. A-G: uppermost Lower Kimmeridgian specimens, Makar'yev Section (S1) (Colpaert et al. 2016; Colpaert, Nikitenko et al. 2017). A-E: bed 2, sample 3. F-G: bed 1, sample 24. H-M: upper Kimmeridgian specimens of the Izhma River Section (S15) (Mesežnikov 1984). H-M: bed 3, sample 114. N-O: uppermost Lower Kimmeridgian specimens, Vyatkina River Section (S13). N-0: top of the bed 7, sample 146. Specimens are shown at the following magnifications: $A-B$ ( $\mathrm{A}$ is microspheric form) $\times 68$; $\mathrm{C}-\mathrm{E}$ (C, E are juvenile forms); $\mathrm{F}-\mathrm{G} \times 42 ; \mathrm{H}-\mathrm{O} \times 56$ (J is megalospheric form; $\mathrm{K}, \mathrm{L}$ are juvenile forms).

Juvenile forms differ from adult forms by their smaller size (L ca. $0.35 \mathrm{~mm}$; W ca. $0.31 \mathrm{~mm}$ ) and highly biconvex test characterized by a conical dorsal side and a strongly inflated ventral side (T/L ca. 0.56). Rare specimens of juvenile forms (Fig. 3C) are characterized by a flat ventral side (T/L min. 0.35). The test consists in a small number of chambers $\left(\mathrm{N}^{\circ}{ }_{\mathrm{ch}}\right.$ ca. 11), distributed over quickly evolving whorls $\left(\mathrm{N}^{\circ}{ }_{\text {ch/lwh }} / \mathrm{N}^{\circ}\right.$ ch ca. 0.57). The chambers may be more (Fig. 3C) or less (Fig. 3K) inflated, and are regularly distributed over the conus in the dorsal side. Sutures may be thin (Fig. 3C, 3E) or already well-developed (Fig. 3L, 3K) on the first whorl ( $\mathrm{T}_{\text {su/ewh }}$ ca. 0.02-0.05 $\mathrm{mm})$ but are never raised. In the peripheral margin, sutures may be thick ( $\mathrm{T}_{\text {su/wh }}$ ca. $0.04 \mathrm{~mm}$ ) and strongly 


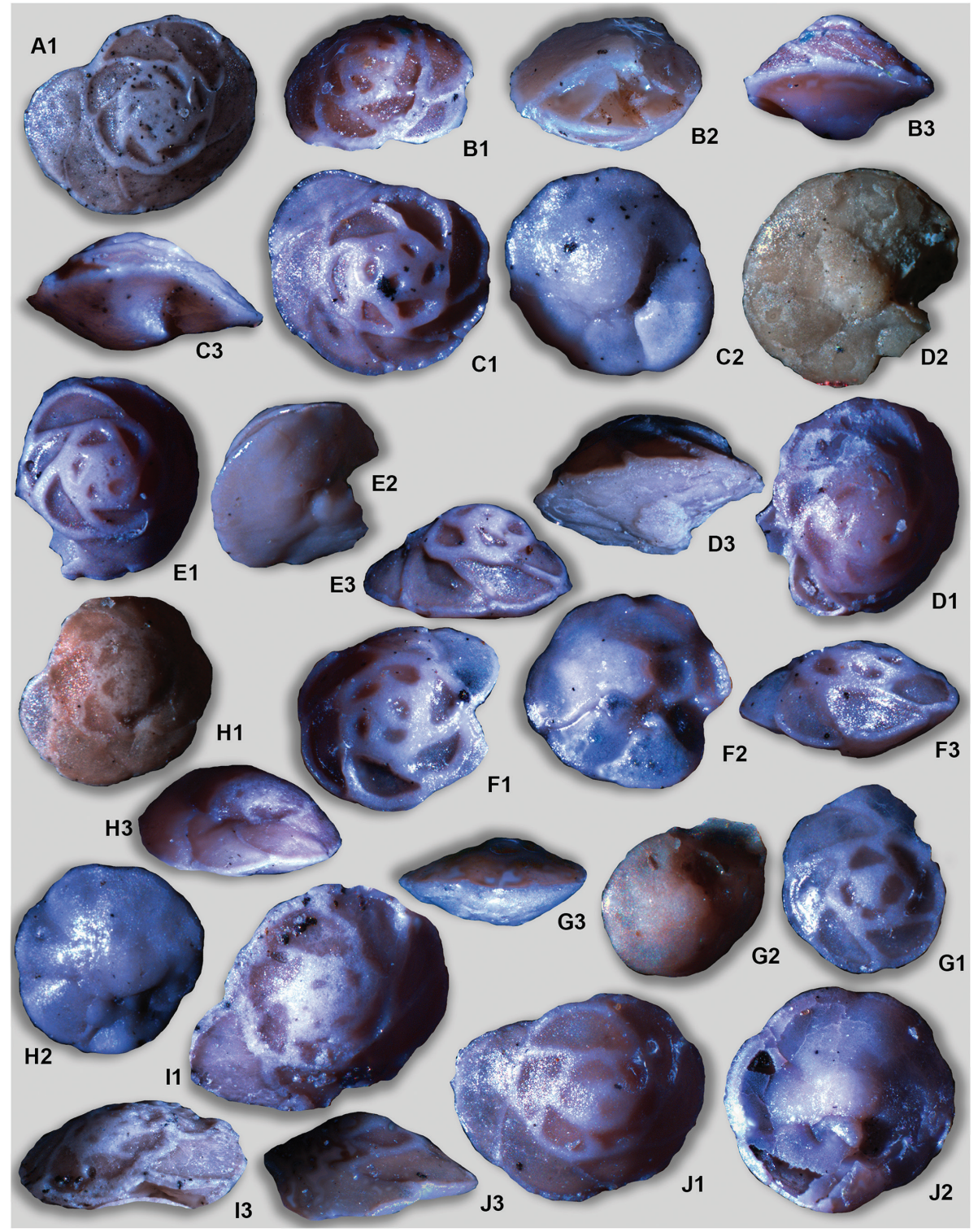

Fig. 4 Dorsal (1), ventral (2) and lateral (3) views of Pseudolamarckina pseudorjasanensis Dain, 1967 specimens in the Upper Kimmeridgian of the central European part of Russia. A-J: Upper Kimmeridgian specimens, Gorodishche Section (S2), bed 1 (Colpaert, Pestchevitskaya et al. 2017). A-C: sample 35. D and E: sample 36. F and G: sample 37. H-J: sample 38. Specimens are shown at the following magnifications: $A \times 38 ; B \times 42 ; C \times 43$ (megalospheric form); D × 33; E × 40 (megalospheric form); F, G × 56; H × 30; I × 45 (microspheric form); J 553 .

bending (Fig. 3k). The aperture is big $\left(\mathrm{L}_{\mathrm{ap}}\right.$ ca. $\left.0.11 \mathrm{~mm}\right)$ and pronounced loop-shaped $\left(\alpha_{\text {ap }}\right.$ ca. $\left.125^{\circ}\right)$.

Microspheric forms are on average characterized by a bigger size (L ca. $0.56 \mathrm{~mm}$; W ca. $0.52 \mathrm{~mm}$ ) than megalospheric forms (L ca. $0.46 \mathrm{~mm}$; W ca. $0.40 \mathrm{~mm}$ ). However, the number of chambers and whorls is not necessarily bigger. Microspheric forms are characterized by a very small initial chamber, hardly visible because of the occurrence of massive overlapping ridges in the middle part of the dorsal side (Figs. 3A, 4I, 5F). Thus, the diameter of the proloculus corresponds to the diameter of the initial chamber and the thickness of the overlapping ridges ( $\mathrm{D}_{\mathrm{pr}}$ ca. $0.13 \mathrm{~mm} ; \mathrm{D}_{\mathrm{pr}} / \mathrm{L}$ ca. 0.22).

Megalospheric forms differ by the occurrence of a differentiated proloculus made of small spherical initial chambers, followed by three to four chambers, from 1.5 to two times smaller in size (Figs. 3J, 4C, 4E, 5A). In megalospheric specimens, the proloculus is highly 


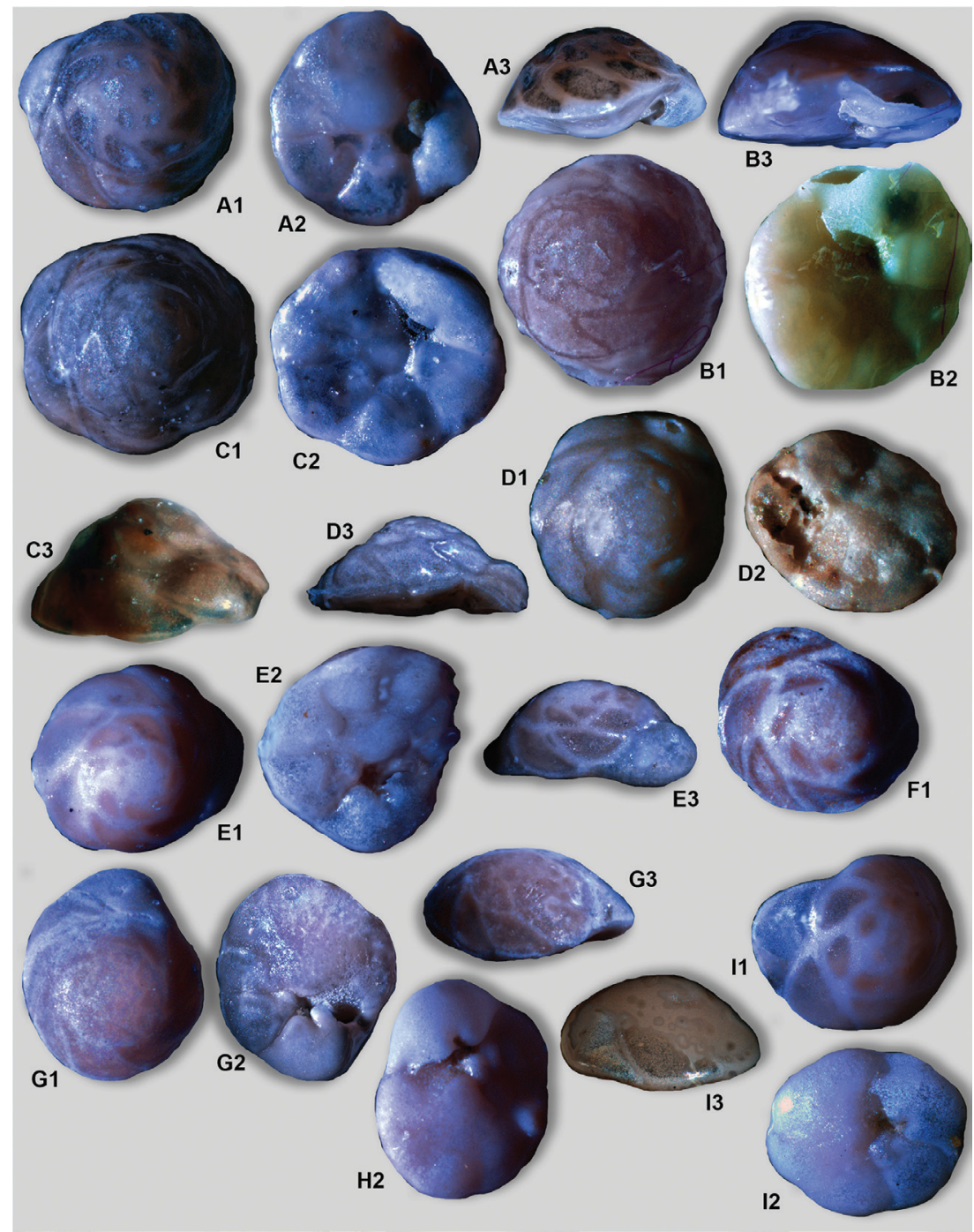

Fig. 5 Dorsal (1), ventral (2) and lateral (3) views of Pseudolamarckina pseudorjasanensis Dain, 1967 specimens in the Lower and Upper Kimmeridgian of Subpolar Ural, Western Siberia, Russia. A-C: Uppermost Lower. E-I: Upper Kimmeridgian specimens of the Lopsiya River Section (S41) (Nikitenko 2009). A-C, G-I: bed 7, sample 31. D: bed 1, sample 13. E-F: bed 2, sample 14. Specimens are shown at the following magnifications: A, B $\times 40$ (A is the megalospheric form); C $\times 42 ; \mathrm{D} \times 49 ; \mathrm{E} \times 28 ; \mathrm{F} \times 36$ (microspheric form); $\mathrm{G} \times 28 ; \mathrm{H} \times 40 ; \mathrm{I} \times 56$

distinguished on the top of the dorsal side, and its diameter can be measured precisely $\left(\mathrm{D}_{\mathrm{pr}}\right.$ ca. $0.07 \mathrm{~mm}$; $\mathrm{D}_{\mathrm{pr}} / \mathrm{L}$ ca. 0.16).

Other variations observed in the specimens of the species P. pseudorjasanensis include: various shapes of dorsal and ventral sides; size and development of sutures. In this way, larger adult specimens $(\mathrm{L}<0.5 \mathrm{~mm})$ are sometimes characterized by a highly developed conical shape in lateral view (T/L until 0.79), with the occurrence of a bulb-shaped proloculus area (Figs. 3A, 3F, 4B, 4J, 5B, 5C). Smaller size adult specimens differ by a more regular dorsal side (Figs. 3D, 3H, 4F, 4J, 5E, 5G). Apart from foraminiferal generations, variations in the shape of the ventral side may be observed. Most of the specimens are characterized by a strongly depressed (Figs. 3A, 3B, $4 \mathrm{~J}, 5 \mathrm{E}, 5 \mathrm{D})$ to flat ventral side (Figs. 3G, 4E, 4H, 5B), whereas rare specimens are characterized by the development of an inflated umbilical zone in the central part of the ventral side (Figs. 3B, 4B, 4C, 4D, 5A). Finally, the development of a suture strongly varies from very thin and smooth $\left(\mathrm{T}_{\text {su/whh }} / \mathrm{T}_{\text {su/ewh }}\right.$ ca. 1 with $\mathrm{T}_{\text {su/ewh }}$ ca. $\left.0.01 \mathrm{~mm}\right)$ (Figs. 3A, 5A, 5B, 5C, 5D, 5E), to thick in the first whorls and thinner in the last whorls $\left(\mathrm{T}_{\text {su/lwh }} / \mathrm{T}_{\text {su/ewh }}\right.$ ca. $0.25-0.33$ with $\mathrm{T}_{\text {su/ewh }}$ ca. $0.05 \mathrm{~mm}$ ) (Figs. 3G, 3F, 4A), to very thick 


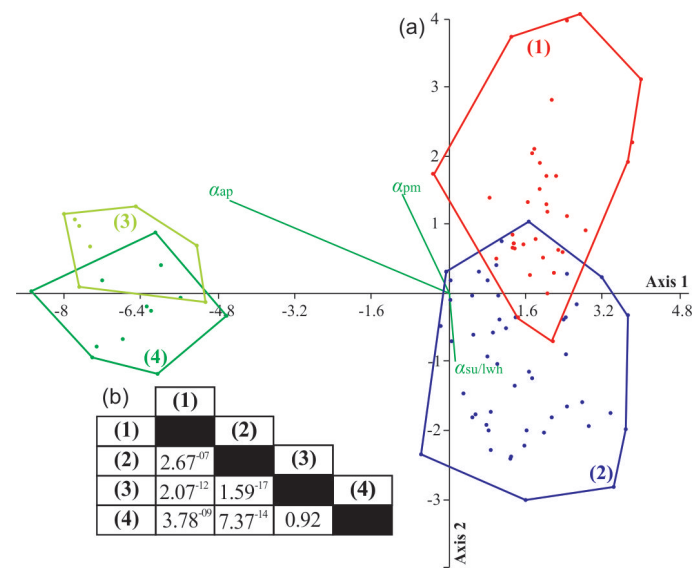

Fig. 6 Canonical variate analysis of the studied taxa of Pseudolamarckina pseudorjasanensis, P. bieleckae, P. voliaensis: (a) biplot of the taxa and (b) multivariate analysis of variance with probabilities of similarity for pair species. and raising all over the spiral of the test $\left(\mathrm{T}_{\text {su/lwh }} / \mathrm{T}_{\text {su/ewh }}\right.$ ca. 1 with $\mathrm{T}_{\text {su/ewh }}$ ca. $0.05 \mathrm{~mm}$ ) (Figs. 3H, 3N, 4C, 4F).

\section{Comparison}

The Upper Callovian species P. rjasanensis (Uhlig, 1883) is morphologically close to the Kimmeridgian form P. pseudorjasanensis but differs by: (1) most extreme development of last whorls characterized by a bigger proportion of chambers $\left(\mathrm{N}^{\circ}{ }_{\text {ch/lwh }} / \mathrm{N}^{\circ}{ }_{\text {ch }}>0.5\right.$ with $\mathrm{N}_{\text {ch/lwh }}^{\circ}$ ca. 8) and (2) less lobate structure of the peripheral margin $\left(\alpha_{\mathrm{pm}}\right.$ ca. $\left.175^{\circ}\right)$.

The Lower Volgian species $P$. bieleckae Dain and Kuznecova, 1976, and P. voliaensis Dain, 1972, respectively, recorded in the central part of European Russia and Western Siberia both differ from the Kimmeridgian

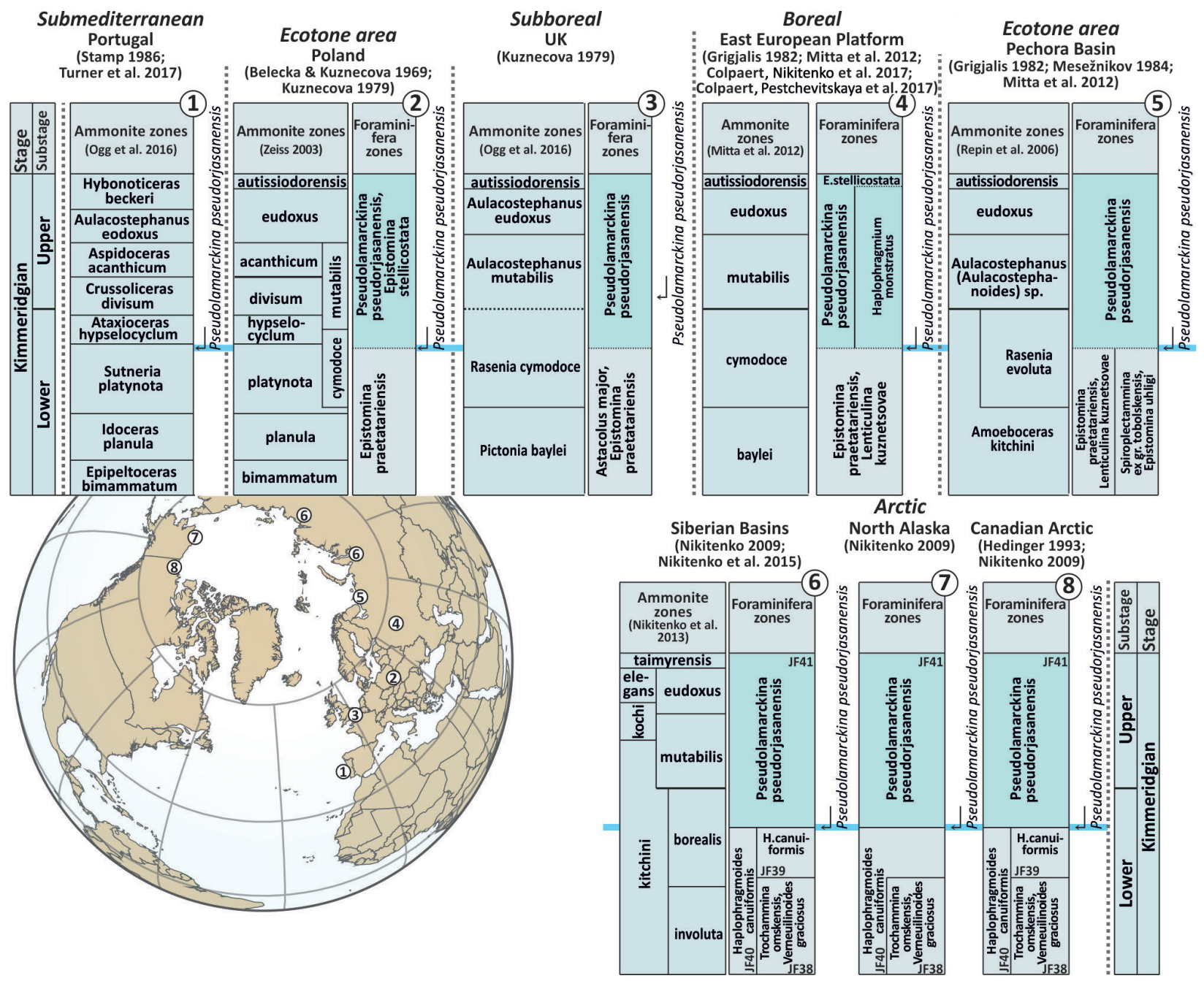

Fig. 7 Comparison of zonal subdivision of the Kimmeridgian of the sub-Mediterranean, sub-boreal, boreal and Arctic realms and first appearance of the Pseudolamarckina pseudorjasanensis in the different regions. 
(a):

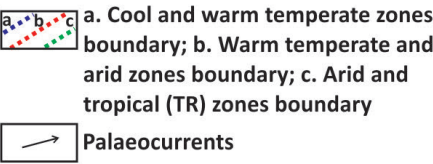

(1) West European Seas (2) Viking corridor (strait)

(3) Russian Sea

(4) South of the Barents Sea

(Pechora Sea)

(5) West Siberian Sea

(6) Yenisei-Khatanga strait

(7) Anabar-Lena Sea

(8) North Alaskan Sea (2) Barents Sea

(10) East European seas

(11) Western North

(b): Foraminiferal Biogeographic Units Boreal-Atlantic Realm: 1. 2. NW European Province; (1). Scotland-Greenland Ecotone Zone 3, 共期 3. East European Province Arctic Realm: A6 4. Pechora Province (Ecotone Zone); 4.4 6. Barents Sea Province 菏册 5. Siberian-North Alaskian Province a. Boreal-Atlantic and Arctic Realms $\therefore$ boundary; b. Ecotone Zones boundary

(c): Pseulamarckina pseudorjasanensis

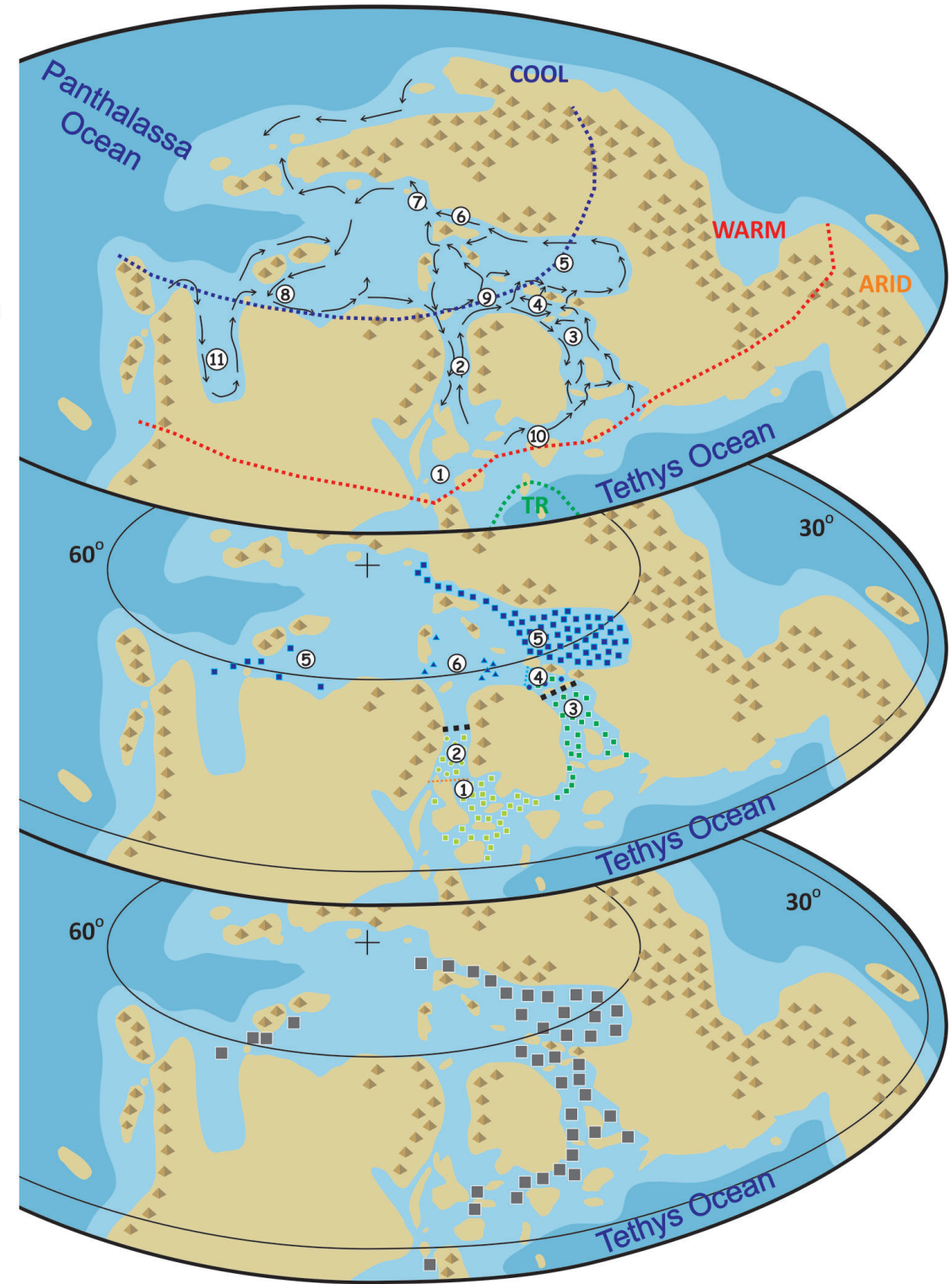

Fig. 8 (a) Palaeogeographical reconstruction and (b) foraminiferal biogeography of the Kimmeridgian North Hemisphere (Boucot et al. 2004, 2013; Nikitenko 2009; Scotese et al. 2014a, b; with modifications). (c) Geographical distribution of P. pseudorjasanensis.

species P. pseudorjasanensis by: (1) less developed last whorls characterized by a lower proportion of chambers $\left(\mathrm{N}^{\circ}{ }_{\mathrm{ch} / \mathrm{lwh}} / \mathrm{N}^{\circ}{ }_{\text {ch }}\right.$ ca. 0.42$)$; (2) distinct proloculus, characterized by a rounded initial chamber never overlapped by ridges on the top of the dorsal side; (3) position and shape of the aperture, characterized by a very small rounded mouth $\left(\mathrm{L}_{\mathrm{ap}}\right.$ ca. 0.05-0.06 mm) located in the dorsal side of the last chamber near/on the peripheral margin $\left(\mathrm{D}_{\mathrm{ap}}\right.$ ca. $0.10-0.18 ; \alpha_{\mathrm{ap}}$ ca. $180^{\circ}$ [= no arcuate]). Furthermore, both of these species are characterized by a suture of regular size through the early to late whorls $\left(\mathrm{T}_{\mathrm{su} / \mathrm{lwh}} / \mathrm{T}_{\text {su/ewh }}=1\right)$. Pseudolamarckina bieleckae is usually characterized by relatively thick sutures $\left(\mathrm{T}_{\text {su/ewh }}\right.$ and $\mathrm{T}_{\text {su/lwh }}$ ca. $0.03 \mathrm{~mm}$ ), whereas the sutures of $P$. voliaensis are thinner $\left(\mathrm{T}_{\text {su/ewh }}\right.$ and $\mathrm{T}_{\text {su/lwh }}$ ca. $0.02 \mathrm{~mm}$ ). The peripheral margin is relatively regular for both of these species but, especially in P. voliaensis, is characterized by an almost perfectly rounded test outline $\left(\alpha_{\mathrm{pm}}\right.$ ca. $\left.172^{\circ}\right)$

\section{Remarks}

Studied specimens of $P$. pseudorjasanensis are characterized by high intraspecific variabilities. Because of these 


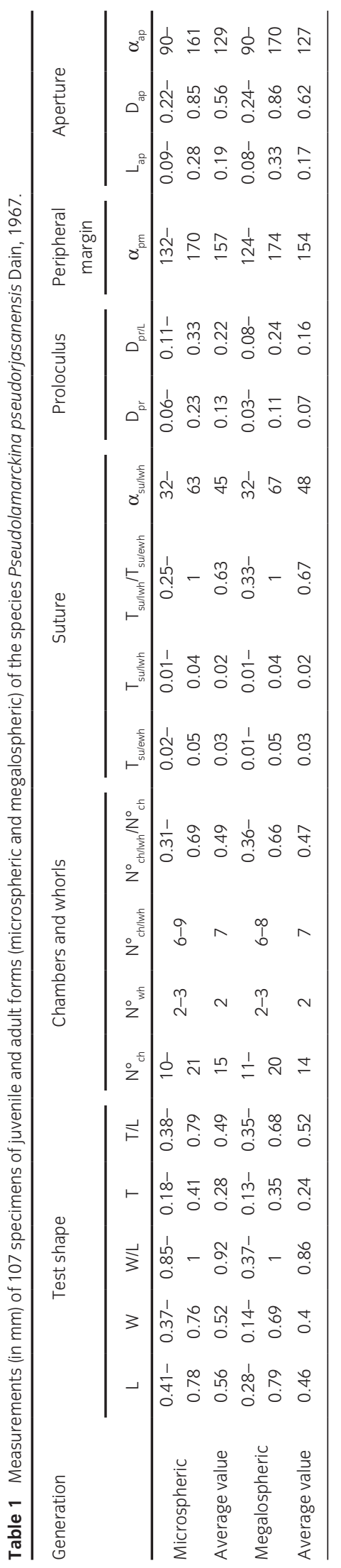

morphological differences, specimens from the Kimmeridgian of the central part of European Russia and Western Siberia were initially considered as a single species (Dain 1972), but may actually belong to different species, including P. pseudorjasanensis, P. lopsiensis and P. liapinensis. In this way, it was mentioned that $P$. lopsiensis differs from P. pseudorjasanensis by the higher number of chambers in the last whorl and from $P$. liapinensis by raised and mat sutures, as well as the less central position of the final aperture in the ventral side (Dain 1972). Finally, P. liapinensis differs from P. pseudorjasanensis by tallest test, smaller development of whorls as well as flat or slightly depressed ventral side, and the absence of depressed peripheral margin. However, the distinction between these species remains unclear, and some authors have attributed specimens from the Kimmeridgian of the Timan-Pechora Basin to the single species P. pseudorjasanensis (Jakovleva \& Azbel' 1993).

In the present study, a projection of the biometric data set has been performed on the basis of the following groups of Pseudolamarckina: the Kimmeridgian species P. pseudorjasanensis from the central part of European Russia and Western Siberia (Subpolar Ural); the Early Volgian species $P$. bieleckae of the central part of European Russia and $P$. voliaensis of Subpolar Ural. The aim is to compare the coefficient of variations through the specimens of a same age, which share different geographical areas and basins with other species from a different stratigraphic interval. The major results of the CVA based on the selected parameters are reported in Fig. 6a. The first axis accounts for about $86 \%$ of the total variation and differentiates groups 1 and 2 (Kimmeridgian forms) from groups 3 and 4 (Early Volgian forms). The second axis accounts for about $9 \%$ of the total variation. As shown by the length and direction of vectors of the studied parameters compared to the canonical vectors, the shape of the aperture is the main parameter to separate Kimmeridgian and Early Volgian forms. Discrimination along the second axis is controlled by the angle of the suture spiral and the lobate arrangement of the peripheral margin. These parameters allow for separating the specimens from the central part of European Russia and Western Siberia. Furthermore, the current analysis demonstrates that the angle of the suture spiral and the lobate arrangement of the peripheral margin differentiate not only the Kimmeridgian forms but also the Early Volgian ones. However, the separation is not really clear since there are still overlaps of extreme values between species from the same stratigraphic range, but sharing different geographical areas. The overall analysis shows that the Kimmeridgian specimens may belong to a single species, characterized by high intraspecific variability (Fig. 6b) and highly differentiated from the Volgian species. 
On the basis of published monographic data, specimens of the genus Pseudolamarckina (Mjatljuk 1959) described from the Lower Kimmeridgian successions of the central part of European Russia and attributed to the species $P$. dainae differ from the previously mentioned species $P$. liapinensis by highly inflated dorsal and ventral sides (Starceva 1972). However, earlier results on the synonymy of the Kimmeridgian specimens from Arctic regions (Levčuk $\&$ Nikitenko 2010) have shown that species $P$. liapinensis must be included in the synonymy of P. lopsiensis. Furthermore, the present study shows that specimens from Western Siberia exhibit a typical morphology for P. pseudorjasanensis. Consequently, both of these species directly fall in the intraspecific variability of P. pseudorjasanensis included specimens with highly inflated dorsal and ventral sides, encompassing typical morphotypes of the species $P$. dainae.

The Upper Kimmeridgian subspecies P. polonica spatiosa was described as a part of P. polonica (Bielecka \& Pozaryski 1954), whose holotype was reported from the Lower Portlandian (= Lower Volgian) strata of the Borehole Zagloba in Poland. The subspecies P. polonica spatiosa differs from the typical representatives of $P$. polonica by the higher quantity of chambers in the last whorls and the smaller thickness of the septal suture. Based on the present study, the different development of the last whorls is recognized as a morphological differentiation between the Kimmeridgian forms of P. pseudorjasanensis and the Lower Volgian forms of P. bieleckae, but the thickness of the suture is attributed to intraspecific variability. Therefore, the subspecies $P$. polonica spatiosa is a direct equivalent of the Kimmeridgian species P. pseudorjasanensis (Dain 1967).

Finally, some specimens of the genus Pseudolamarckina attributed to the Middle-Late Callovian species P. rjasanensis have been recorded in the Lower Kimmeridgian of north Portugal (Stam 1986) and the central part of the European Platform (Umanskaja 1965). The north Portugal forms of P. rjasanensis display all the typical morphological characteristics of the species $P$. pseudorjasanensis, including a convex spiral side, broad and slightly raised sutures, last chamber extended towards the centre and almost covering the umbilicus and a loop-shaped, umbilical aperture (Stam 1986). Similar specimens were recorded in the upper part of Lower Kimmeridgian strata of the Tojeira Section (north Portugal) associated to the upper part of the ammonite Platynota Zone and/or to the base of the ammonite Hypselocylum Zone (Stam 1986; Turner et al. 2017) (Fig. 7). According to interregional biostratigraphical correlations, this level corresponds to the middle part of the ammonite Cymodoce Zone of the sub-boreal and boreal regions (Kuznecova 1979; Grigjalis 1982; Mitta et al. 2012; Colpaert, Nikitenko et al. 2017;
Colpaert, Pestchevitskaya et al. 2017), the middle part of the ammonite Evoluta Zone of the Pechora ecotone (boreal to Arctic) (Grigjalis 1982; Mesežnikov 1984; Mitta et al. 2012) and the middle part of the ammonite Borealis Zone of the Arctic (Nikitenko 2009), which in this case correspond to the lower boundary of the foraminiferal Pseudolamarckina pseudorjasanensis JF41 Zone.

\section{Stratigraphical range and geographical distribution}

Uppermost Lower Kimmeridgian-Upper Kimmeridgian; northern Portugal, England, north-western France, Poland, European Russia, Kazakhstan, Caucasus, Western and Eastern Siberia, Arctic Alaska and Canada.

\section{Biostratigraphy}

The Kimmeridgian representatives of the genus Pseudolamarckina are very important in biostratigraphical analyses and are often used for biostratigraphic zonation. The foraminiferal Brotzenia (= Epistomina) stellicostata, Pseudolamarckina polonica (= P. pseudorjasanensis) Zone was initially defined in the Upper Kimmeridgian clay of the Gorodishche Section (Kuznecova 1979). However, further investigations of the taxonomical composition of the genus Pseudolamarckina demonstrated that species P. polonica is a typical Volgian form, whereas Kimmeridgian representatives of this genus must be attributed to P. pseudorjasanensis (Kamyševa-Elpat'evskaja 1967; Dain \& Kuznecova 1976). These observations resulted in the designation of the Upper Kimmeridgian foraminiferal zone as the P. pseudorjasanensis Zone (Dain \& Kuznecova 1976; Kuznecova 1979; Grigjalis 1982).

Later analyses of the material from the central part of European Russia have shown that the first appearance data of the species P. pseudorjasanensis have to be extended to the uppermost Lower Kimmeridgian (Nikitenko 2009; Mitta et al. 2012; Colpaert et al. 2016; Colpaert, Nikitenko et al. 2017), where the first changes in the composition of the zonal assemblage were also defined (Fig. 7). This extension resulted in the adjustment of the stratigraphical range of the foraminiferal P. pseudorjasanensis JF41 Zone from the uppermost Lower to Upper Kimmeridgian.

Further investigations of Kimmeridgian foraminifers have shown that JF4l Zone is widespread across boreal and sub-boreal regions. The characteristic assemblage of the foraminiferal P. pseudorjasanensis Zone was first identified in southern England (Kuznecova 1979). Although the occurrence of the index-species was identified in the Upper Kimmeridgian (sensu stricto) only, the lower boundary of the foraminiferal zone was established in the uppermost Lower Kimmeridgian (upper part of 
the ammonite Cymodoce Zone) based on changes in the composition of the foraminiferal assemblages. Similar foraminiferal assemblages including the species $P$. pseudorjasanensis and E. stellicostata were identified in the uppermost Lower and Upper Kimmeridgian of Poland (Belecka \& Kuznecova 1969; Kuznecova 1979).

Specimens of the genus Pseudolamarckina were found in sub-Mediterranean and peri-Tethyan regions within the uppermost Lower Kimmeridgian strata of Portugal and the Caucasus (Grigjalis 1982; Stam 1986; Turner et al. 2017). Similarly, the species $P$. rjasanensis (= pseudorjasanensis) was identified in the uppermost Lower Kimmeridgian successions of the Tojeira Section (north Portugal), associated to the boundary between the Platynota and Hypselocylum zones. The first occurrence data of the species $P$. pseudorjasanensis, as well as the typical assemblage of the foraminiferal P. pseudorjasanensis Zone, were identified in the upper part of the Lower Kimmeridgian of the northern Caucasus sections (Grigjalis 1982).

Simultaneously, the Kimmeridgian local foraminiferal zones of Siberia (P. liapinensis and P. lopsiensis) were already attributed to the single foraminiferal P. lopsiensis JF41 Zone (uppermost Lower to Upper Kimmeridgian) as it has been demonstrated that representatives of P. liapinensis and P. lopsiensis belonged to a single species (Nikitenko 2009; Levčuk \& Nikitenko 2010). The stratigraphical range of the JF41 Zone was defined on the basis of recorded specimens from the following ammonite Evoluta or Borealis, Kitchini, Mutabilis, Eudoxus, Autissiodorensis and Taimyrensis zones (Fig. 7). Finally, the nomenclature of the foraminiferal P. lopsiensis JF41 Zone was later changed to the foraminiferal P. pseudorjasanensis JF4l Zone (Nikitenko et al. 2015).

Analyses of the Kimmeridgian successions of Arctic Alaska and Canada showed foraminiferal assemblages almost identical to foraminiferal assemblages of Siberia (Hedinger 1993; Nikitenko 2009) (Fig. 7). Assemblages rich in specimens of the genus Pseudolamarckina were also noticed in this interval. In addition, Kimmeridgian assemblages are characterized by abundant typical warm-water foraminifers, such as those coevally observed in other sections from boreal and Arctic regions.

The foraminiferal P. lopsiensis Zone (uppermost Lower and Upper Kimmeridgian) of the northern part of European Russia (Timan-Pechora Basin) is defined by the periodic accumulations of Pseudolamarckina. Initially identified as the Siberian species P. lopsiensis, specimens of Pseudolamarckina were later attributed to the species $P$. pseudorjasanensis (Jakovleva \& Azbel' 1993; Lyjurov 1996). This change in species attribution resulted in the review of the nomenclature of the Kimmeridgian zone as the P. pseudorjasanensis Zone (Mitta et al. 2012) (Fig. 7).
To conclude, the Kimmeridgian foraminiferal P. pseudorjasanensis JF4l Zone appears to be an important interregional marker, which is used for the correlation of various widespread sections across sub-boreal, boreal and Arctic basins. The first occurrence of the species P. pseudorjasanensis is recognized in a coeval level, associated to the uppermost Lower Kimmeridgian of subMediterranean and peri-Tethyan (Portugal, Caucasus) to Arctic (Laptev Sea coast, Arctic Alaska and Canada) regions (Fig. 7) (Kuznecova 1979; Grigjalis 1982; Mesežnikov 1984; Stam 1986; Hedinger 1993; Nikitenko 2009; Mitta et al. 2012; Nikitenko et al. 2013; Nikitenko et al. 2015; Turner et al. 2017).

\section{Biogeography and palaeoecology}

From the end of the Late Oxfordian to the beginning of the Early Kimmeridgian, the whole territory of boreal and Arctic basins underwent a global transgression, associated with a continuous rise in temperature (Zaharov 1983, 1994; Riboulleau et al. 1998; Zakharov et al. 2005; Nikitenko 2009; Nunn et al. 2009). At that time, significant taxonomical and structural changes occurred in the microfaunal associations of the boreal and Arctic seas, including the replacement of many dominant taxa and the increase in abundance of typical sub-boreal and sub-Mediterranean migrant species (Nikitenko et al. 2005; Nikitenko 2009; Colpaert, Nikitenko et al. 2017; Colpaert, Pestchevitskaya et al. 2017).

During the Late Jurassic, the warm climate area extended across all territories currently located in north-western and north-eastern Europe, as well as south-western Siberia, Alaska and Canada, whereas arid and tropical climates dominated in south-western and south-eastern Europe, Middle East and Central Asia (Fig. 8a). The cool climate area was then restricted to the territories currently located in the Arctic part of Europe, north-western and Eastern Siberia, northern Alaska and Canada (Boucot et al. 2004, 2013; Scotese et al. 2014a, b). The continuous transgressive phase and warmer temperatures may thus have favoured connections between sub-Mediterranean, sub-boreal, boreal and Arctic regions (Fig. 8a), resulting in massive microfossil migrations.

The formerly established biogeographical zonation (Nikitenko 2009) was based on undertaking statistical (clustering) methods, including binary database (presence or absence of taxa), group average link method and Jaccard coefficient index, and showed that foraminiferal associations of the northern boreal-Atlantic and the Arctic exhibit the highest level of generic similarities during the end of the Early and the Late Kimmeridgian (Nikitenko 2009). 
During the end of the Early and the Late Jurassic, the foraminiferal associations of the Arctic seas were for the first time periodically dominated by typical genera from the boreal-Atlantic basins, although microbenthic associations from the Siberian and North Alaskan Province sustained a high level of similarities (Fig. 8b). The most important taxa were represented by species belonging to the genera Pseudolamarckina, Lenticulina, Astacolus, Trochammina, Glomospirella, Haplophragmoides and Recurvoides, among others. In contrast, the Barents Sea Province is characterized by relatively poor foraminiferal associations compared to the Siberian and American ones (potentially due to less studied sections), and is represented by specimens of the genera Trochammina, Ammodiscus, Haplophragmoides, Ammobaculites, Recurvoides, Bulbobaculites, Spiroplectammina, Evolutinella, Cancrisiella and others (Nikitenko 2009).

An ecotone region has been identified in the Pechora Sea (Pechora Province). It is characterized by foraminiferal assemblages defined by abundant representative taxa similar to those of the Russian Sea (East European Province) and Arctic basins (Fig. 8b). Foraminiferal migrations may thus have occurred between the Pechora and the Western Siberian basins across the Ural Archipelago straits.

The Russian Sea (East European Province) was, in turn, dominated by representatives of the genera Pseudolamarckina, Epistomina, Lenticulina and Marginulina, as well as abundant specimens of the genera Spirillina, Astacolus, Nubecularia, Kutsevella, Pseudonodosaria, Dentalina, Haplophragmoides and others that were also recorded in typical assemblages of the western European Sea (north-western European Province) (Fig. 8b).

Finally, Kimmeridgian representatives of the genus Pseudolamarckina were widespread across the Northern Hemisphere, from Portugal to Siberia, Arctic Alaska and Canada (Fig. 8c), and constituted a significant part of the foraminiferal associations. The habitat of the Early to Late Kimmeridgian Pseudolamarckina associations was restricted to the boundary between warm temperate and arid zones in the south of the Northern Hemisphere, and extended to the southern boundary of the cool zone towards the north (Fig. 8). At that time, the boreal and Arctic seas were characterized by the deposition of clay and silt associated with a general rise in sea level. In the middle sublittoral zone, characterized by normal salinity and high oxygenation, the development of fine-grained marine sediments may have favoured foraminiferal associations dominated by Pseudolamarckina (Nikitenko 2009; Colpaert, Pestchevitskaya et al. 2017), whereas they markedly decrease in abundance in the upper and lower sublittoral zones.
Foraminiferal associations dominated by Pseudolamarckina are commonly encountered in boreal seas (central and southern parts of the Russian Sea), whereas they are more unevenly distributed towards the north, in Arctic and Subarctic basins. Note that Arctic and Subarctic basins were characterized by changes in the abundance and preservation of the foraminiferal assemblages, ranging from agglutinated rich-associations to those enriched by calcareous forms. Foraminiferal associations from the middle sublittoral zone of the north American basins are dominated by Pseudolamarckina, Verneuilinoides and Cancrisiella, and are rich in Lenticulina, Citharina, Geinitzinita, Saracenaria and Evolutinella, among others (Hedinger 1993; Nikitenko 2009).

Finally, specimens of the genus Pseudolamarckina are rarely recorded in environments dominated by calcareous deposits from the sub-boreal and sub-Mediterranean regions. In that way, the highest quantity of representatives of the genus Pseudolamarckina are identified in the Russian Sea, and progressively decreases towards northern and southern regions.

\section{Conclusion}

The current taxonomic review has shown that both the studied European Russian and Western Siberian Kimmeridgian representatives of the genus Pseudolamarckina must be attributed to a single species, namely, P. pseudorjasanensis, according to the priority rule. Typical forms of the species P. pseudorjasanensis include the Early Kimmeridgian species $P$. dainae, Kimmeridgian subspecies of $P$. polonica spatiosa as well as some specimens of $P$. rjasanensis. This is important for the Kimmeridgian foraminiferal biozonation of sub-boreal to Arctic regions. The first appearance data of the Kimmeridgian marker species P. pseudorjasanensis is recorded in the uppermost Lower Kimmeridgian of peri-Tethyan and Arctic regions (Fig. 7). Therefore, the geographical distribution of the foraminifera P. pseudorjasanensis JF41 Zone should be extended to Western Siberia and Arctic Canada (Fig. 8).

In terms of palaeobiogeographical and palaeoecological significance, the wide distribution of P. pseudorjasanensis across the boreal-Atlantic and the Arctic was favoured by continuous transgressive phases and rising temperatures that may have favoured connections between subMediterranean, sub-boreal, boreal and Arctic regions. Finally, P. pseudorjasanensis associations are commonly recorded in fine-grained marine sediments, including clays and silty deposits, predominantly associated with middle sublittoral zones. The highest quantity of Kimmeridgian representatives of the genus Pseudolamarckina is identified in the Russian Sea, and their abundance progressively declines towards the northern and southern regions. 


\section{Acknowledgements}

We wish to express our sincere gratitude to the reviewers Prof. Felix Gradstein, Prof. Michael A. Kaminski and Dr E.B. Pestchevitskaya for their valuable comments, helpful suggestions and careful review of the manuscript. We are grateful to Dr G. Lymer for his helpful comments and review.

\section{Disclosure statement}

No potential conflicts of interest was reported by the author.

\section{Funding}

Financial support from the Russian Science Foundation under project no. 18-17-00038 and RFBR no. 18-0570035 is gratefully acknowledged.

\section{References}

Azbel' A. Ja. \& Grigjalis [Grigelis] A.A. (eds.) 1991. Praktičeskoe rukovodstvo po mikrofaune SSSR. T. 5. Foraminifery mezozoja. (Practical guide to the microfauna of the USSR. Vol. 5. Mesozoic foraminifers.) Leningrad: Nedra Publishers.

Belecka [Bielecka] W. \& Kuznecova [Kuznetsova] K.I. 1969. Foraminifery i paleogeografija kimeridžskogo veka Vostočnoj Evropy (Pol'ša i Evropejskaja čast' SSSR) (Foraminifers and palaeogeography of the Kimmeridgian Stage of eastern Europe [Poland and European part of the USSR].) Voprosy Mikropaleontologii 12, 58-80.

Bielecka W. \& Pozaryski W. 1954. Stratygrafia mikropaleontologiczna gornego malmu $w$ Polsce Srodkowej.(Micropalaeontological stratigraphy of the Upper Malm in central Poland.) Warszawa: Instytut Geologiczny, Prace.

Boucot A.J., Xu C. \& Scotese C.R. 2004. Phanerozoic climatic zones and paleogeography with a consideration of atmospheric $\mathrm{CO}_{2}$ levels. Paleontological Journal 38, 115-122.

Boucot A.J., Xu C. \& Scotese C.R. 2013. Phanerozoic paleoclimate: an atlas of lithologic indicators of climate. SEPM concepts in sedimentology and paleontology 11. http://dx.doi.org/10.2110/ sepmcsp.11. Tulsa: Society for Sedimentary Geology.

Bulynnikova S.P., Komissarenko V.K., Belousova N.A., Bogomjakova G.T., Ryl'kova G.E. \& Tylkina K.E. 1990. Atlas molljuskov $i$ foraminifer morskih otlojenij verhnej jury $i$ neokoma Zapadno-Sibirskoj neftegazonosnoj oblasti. T. 2. Foraminifery. (Atlas of mollusks and foraminifers of marine deposits of the Upper Jurassic and Neocomian of the West Siberian oil and gas region. Vol. 2. Foraminifers.) Moscow: Nedra Publishers.

Bykova E.V. 1948. O znašenii iskopaemyh foraminifer dlja stratigrafii jurskih otloženij rajona Samarskoj Luki. (The significance of fossil foraminifers for the stratigraphy of the Jurassic deposits of the Luki Samara region.) In A.V.
Fursenko (ed.): Mikrofayna neftjanyh mestoroždenij SSSR. (Microfauna of oil deposits from the USSR.) Vol. 31. Pp. 82-108. Moscow: Gostoptekhizdat.

Colpaert C., Nikitenko B.L. \& Khafaeva S.N. 2017. Stratigraphy and ecostratigraphic distribution of foraminiferal morphogroups from the Upper Jurassic of the Makar'yev Section (Unzha River, Volga River Basin). Russian Geology and Geophysics 58, 69-85, http://dx.doi.org/10.1016/j. rgg.2016.04.014.

Colpaert C., Nikitenko B., Khafaeva S. \& Wall A.F. 2016. The evolution of Late Callovian to Early Kimmeridgian foraminiferal associations from the central part of the Russian Sea (Makar'yev Section, Volga River Basin, Russia). Palaeogeography, Palaeoclimatology, Palaeoecology 451, 97-109, http://dx.doi.org/10.1016/j.palaeo.2016.03.014.

Colpaert C., Pestchevitskaya E.B. \& Nikitenko B.L. 2017. Upper Jurassic foraminifera, dinoflagellates and terrestrial sporomorphs from the Gorodishche Section (Ul'yanovsk Region, East European Platform, Russia): biostratigraphic, palaeoenvironmental and palaeobiogeographical implications. Revue de Micropaléontologie 60, 549-572, http://dx. doi.org/10.1016/j.revmic.2017.10.001.

Cushman J.A. 1927. An outline of a re-classification of the foraminifera. Contributions from the Cushman Laboratory for Foraminiferal Research 3. Sharon, MA: Cushman Laboratory for Foraminiferal Research.

Dain L.G. (ed.) 1972. Foraminifery verhnejurskih otloženij zapadnoj Sibiri. (Foraminifers of the Upper Jurassic deposits of western Siberia.) Leningrad: Nedra Publishers.

Dain L.G. \& Kuznecova [Kuznetsova] K.I. 1976. Foraminifery stratotipa volžskogo jarusa. (Foraminifers of the Volgian stage stratotype.) Moscow: Nauka.

Delage Y. \& Hérouard E. 1896. Traité de zoologie concrète. Vol. 1. La cellule et les protozoaires. (Treaty of concrete zoology. Vol. 1. Cell and protozoa.) Paris: Schleider Frères.

Eichwald C.E. 1860. Zoologie specialis. Vol. 2. (Speciality zoology. Vol. 2.) Vilnae: D.E. Eichwaldus.

Glinskikh L.A., Nikitenko B.L. \& Shurygin B.N. 1999. The Jurassic of western Siberia-the Abalakskaya Formation (palaeontological characteristics, litho- and biostratigraphy). Russian Geology and Geophysics 40, 1059-1078.

Grigjalis [Grigelis] A.A. (ed.) 1982. Biostratigrafija verhnejurskih otloženij SSSR po foraminiferam. (Biostratigraphy of the Upper Jurassic deposits of the USSR based on foraminifers.) Moscow: Vil'nyus.

Hammer Ø. \& Harper D.A.T. 2006. Paleontological data analysis. Oxford: Blackwell Publishing.

Hedinger A. 1993. Upper Jurassic (Oxfordian-Volgian) foraminifera from the Kusky Formation, Aklavik Range, District of MacKenzie, Northwest Territories. Ottawa: Geological Survey of Canada.

Jakovleva [Yakovleva] S.P. \& Azbel' A. Ja. 1993. Sopostavlenie verhnekimeridžskih otloženij rysskoj platformy po foraminiferam. (Comparison of the Upper Kimmeridgian deposits of the Russian Platform based on foraminifers.) In M.S. Mesežnikov (ed.): Stratigrafija fanerozoja neftegazonosnyh regionov rossii. (Stratigraphy of the Phanerozoic from the oil and gas regions of Russia.) Pp. 133-146. St. Petersburg: All-Russia Petroleum Research Exploration Institute. 
Kamyševa-Elpat'evskaja [Kamysheva-Elpatievskaya] V.G. (ed.) 1967. Atlas mezozojskoj fauny i sporovo-pyl'cevyh kompleksov Nižnego Povolž'ja i soprelek'nyh oblastej. Obščaja čast' foraminifery. (Atlas of Mesozoic fauna and spore-pollen complexes of the Lower Volga and adjacent areas. Vol. I. General part. Foraminifers.) Saratov: Izdatel'stvo Saratovskogo Universiteta.

Kuznecova [Kuznetsova] K.I. 1979. Stratigrafija i paleobiogeografijapozdnej jury Boreal'nogo pojasa po foraminiferam. (Stratigraphy and palaeobiogeography of the Late Kimmeridgian boreal realm based on foraminifers.) Moscow: Nauka.

Levčuk [Levchuk] L.K. \& Nikitenko B.L. 2010. Kellovejskie i pozdnejurskie foraminifery zapadnoj i central'noj častej zapadno-Sibirskoj nizmennosti. (Callovian and Late Jurassic foraminifers from eastern and central part of the western Siberian lowlands.) Novosti paleontologii $i$ stratigrafii: priloženie k žurnalu "Geologija i Geofizika" (Palaeontological and stratigraphical news: supplement to the journal Geology and Geophysics) 51(14), 85-110.

Loeblich A.R. \& Tappan H. 1987. Foraminiferal genera and their classification. New York: Van Nostrand Reinhold.

Lyjurov S.V. 1996. Jurskie otloženija severa rysskoj plity. (Jurassic strata of sections from the northern Russian plate.) Ekaterinburg: Ural Department of the Russian Academy of Sciences.

Mesežnikov M.S. 1984. Kimeridžskij $i$ volžskij jarucy severa SSSR. (Kimmeridgian and Volgian stages of northern USSR.) Moscow: Nedra.

Mitta V.V., Alekseev A.S. \& Šik S.M. (eds.) 2012. Unificirovannaja Regional'naja Stratigrafičeskaja Shema Jurskih Otloženij Vostočho-Evropejskoj Platformy. (Unified regional stratigraphic scheme of the Jurassic of the East European Platform. Explanatory note.) Moscow: Paleontological Institute, Russian Academy of Sciences, All-Russia Petroleum Research Exploration Institute.

Mjatljuk E.V. 1953. Iskopaemye foraminifery SSSR. Spirillinidy, rotaliidy, épistominidy $i$ asterigerinidy. (Fossil foraminifers of the USSR. Spirilliniids, rotaliids, epistominiids and asterigeriniids.) Leningrad: Gostoptehizdat, All-Russia Petroleum Research Exploration Institute.

Mjatljuk E.V. 1959. Foraminifery nižnego kelloveja bassejna reki Karly Tatarskoj ASSR. (Lower Callovian foraminifers of the Karly River Basin, Tatarstan, ASSR.) Trudy All-Russia Petroleum Research Exploration Institute 136, 396-433.

Nikitenko B.L. 2009. Stratigrafija, paleobiogeografija i biofacii jury Sibiri po mikrofaune (foraminifery $i$ ostracody). (Stratigraphy, palaeobiogeography, and biofacies of the Jurassic deposits of Siberia based on microfauna [foraminifers and ostracods].) Novosibirsk: Parallel.

Nikitenko B.L., Knyazev V., Pestchevitskaya E.B. \& Glinskikh L.A. 2015. The upper Jurassic of the Laptev Sea: interregional correlations and palaeo environments. Russian Geology and Geophysics 56, 845-872, http://dx.doi.org/10.1016/j. rgg.2015.07.008.

Nikitenko B.L., Levchuk L.K. \& Khafaeva S.N. 2005. Latest Middle-Late Jurassic evolution and facies of foraminifers in west Siberia. Russian Geology and Geophysics 5, 537-556.

Nikitenko B.L., Shurygin B.N., Knyazev V.G., Meledina S.V., Dzyuba O.S., Lebedeva N.K., Peshchevitskaya E.B.,
Glinskikh L.A., Goryacheva A.A. \& Khafaeva C.N. 2013. Jurassic and Cretaceous stratigraphy of the Anabar area (Arctic Siberia, Laptev Sea coast) and the boreal zonal standard. Russian Geology and Geophysics 54, 808-837, http://dx.doi.org/10.1016/j.rgg.2013.07.005.

Nunn E.V., Price G.D., Hart M.B., Page K.N. \& Leng M.J. 2009. Isotopic signals from Callovian-Kimmeridgian (Middle-Upper Jurassic) belemnites and bulk organic carbon, Staffin Bay, Isle of Skye, Scotland. Journal of the Geological Society of London 166, 633-641, http://dx.doi. org/10.1144/0016-76492008-067.

Riboulleau A., Baudin F., Daux V., Hantzpergue P., Renard M. \& Zakharov V. 1998. Evolution de la paléotempérature des eaux de la plate-forme russe au cours du Jurassique supérieur. (Sea-surface paleotemperature evolution of the Russian platform during the Upper Jurassic.) Comptes Rendus de l'Académie des Sciences, Série II, Fascicule A-Sciences de la Terre et des Planètes 326, 239-246.

Scotese C.R., Boucot A.J. \& Xu C. 2014a. Atlas of Phanerozoic climatic zones (Mollweide Projection). Vol. 1-6. Evanston, IL: Paleomap Project, PaleoAtlas for ArcGIS.

Scotese C.R., Boucot A.J. \& Xu C. 2014b. Atlas of Jurassic paleogeographic maps. Paleomap atlas for ArcGIS. Vol. 4. The Jurassic and Triassic. Maps 32-42. Mollweide Projection. Evanston, IL: Paleomap Project, PaleoAtlas for ArcGIS.

Seiglie G.A. \& Bermúdez P.J. 1965. Monografía de la familia de foraminíferos Glabratellidae. (Monograph on the Glabratellidae family of foraminifera.) Geos 12, 15-65.

Smoleń J. \& Iwańczuk J. 2018. Foraminiferal biostratigraphy of the Middle and Upper Jurassic of the Polish Lowlands: the state of the art. Geological Quarterly 62, 257-286, http:// dx.doi.org/10.7306/gq.1406.

Stam B. 1986. Quantitative analysis of Middle and Late Jurassic foraminifera from Portugal and its implications for the grand banks of Newfoundland. Utrecht Micropaleontological Bulletins 34. Utrecht: Schotanus \& Jens.

Starceva [Startseva] G.N. 1972. Opyt biometričeskogo izučenija predstavitelej r. Pseudolamarckina iz verhnejurskih otloženij mejduječ’ja Mokši I Civilja. (Biometrical analysis of the studied species of Pseudolamarckina from the Upper Jurassic sucessions of the Moksha and Tsivil interfluves.) In N.S. Morozova \& V.A. Garjainova (eds.): Voprosy Geologii južnogo Yrala i Povolž'ja, Vypusk 8, čast' 1. (Geological questions on southern Ural and Lower Volga regions. Vol. 8, part 1.) Pp. 103-121. Saratov: Izdatel'stvo Saratovskogo Universiteta.

Turner H.E., Gradstein F.E., Gale A.S. \& Watkins D.K. 2017. The age of the Tojeira Formation (Late Jurassic, Early Kimmeridgian), of Montejunto, west-central Portugal. Swiss Journal of Palaeontology 136, 287-299, http://dx.doi. org/10.1007/s13358-017-0137-6.

Uhlig V. 1883. Über Foraminiferen aus dem rjäsan'schen Ornatenthone. (Foraminifera from the Ryazan Ornathenthone.) Jahrbuch der Kaiserlich-Königlichen Geologischen Reichsanstalt (Vienna) 33, 753-774.

Umanskaja E.G. 1965. Foraminifery nižnego kimeridža Kostromskoj oblasti. (Foraminifers of the Lower 
Kimmeridgian of the Kostroma region.) In E.G. Čapovskij (ed.): Sbornik statej po geologii i gidrogeologii. (Collections of papers on geology and hydrology.) Pp. 84-101. Nedra: Moscow. Zaharov [Zakharov] V.A. (ed.) 1983. Paleobiogeografija i biostratigrafija jury i mela Sibiri. (Jurassic and Cretaceous palaeobiogeography and biostratigraphy of Siberia.) Moscow: Nauka. Zakharov V.A. 1994. Climatic fluctuations and other events in the Mesozoic of the Siberian Arctic. In D.K. Thurston \&
K. Fujita (eds.): Proceedings of the International Conference on Arctic Margins, Anchorage, Alaska, September 1992. Pp. 23-28. Alaska, AK: U.S. Dept. of the Interior, Minerals Management Service, Alaska Outer Continental Shelf Region.

Zakharov V.A., Baudin F., Dzyuba O.S., Daux V., Zverev K.V. $\&$ Renard M. 2005. Isotopic and faunal record of high paleotemperatures in the Kimmeridgian of the Subpolar Urals. Russian Geology and Geophysics 1, 3-20. 